\title{
An outline of achievements in selected areas of forest research in Ireland 1960-2021
}

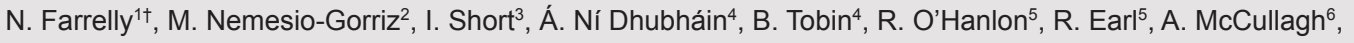 \\ C. O'Donoghue ${ }^{7}$, M. Ryan ${ }^{1}$
}

${ }^{1}$ Teagasc, Mellows Centre, Athenry, Co. Galway, Ireland

${ }^{2}$ Previously, FORM Project Researcher, Teagasc Ashtown, Co. Dublin, Ireland

${ }^{3}$ Teagasc, Ashtown Research Centre, Co. Dublin, Ireland

${ }^{4}$ UCD Forestry, Agriculture and Food, Belfield, Dublin 4, Ireland

${ }^{5}$ Department of Agriculture, Food and the Marine, Backweston, Co. Kildare, Ireland

${ }^{6}$ Department of Agriculture, Food and the Marine, Kildare Street, Dublin 2, Ireland

${ }^{7}$ Department of Economics, National University of Ireland, Galway, Ireland

Abstract

In this paper, we provide an overview of achievements in forest research in Ireland carried out by various agencies over the past $60 \mathrm{yr}$. Many of the outcomes of the research have ensured that policy and practice are well-founded, and many of the research results form the basis of current forest standards and practice. Forest research has, and will continue to have, a significant role in national policy development and international reporting commitments. The achievement of future goals and targets is increasingly dependent on the maintenance of the goods and services that forests provide; these can be enhanced through the establishment of new forests and by appropriate management of the resource (e.g. The EU Green Deal and EU Forest Strategy). We outline the current state of knowledge which can be used to inform afforestation goals and the importance of tree improvement, forest management and forest protection to improve competitiveness and sustainability. Research into forestry and carbon provides a focus on the opportunities and challenges of climate change to Irish forestry. Future efforts will involve longer-term monitoring of environmental change commensurate with the forest rotation to reduce the uncertainties associated with climate change. Research into forestry economics, attitudinal surveys and behavioural studies may help inform the achievement of future policy goals. Reducing the impacts of biotic attack through efficient surveying, disease monitoring and assessing future risk is likely to be the focus of future research effort.

Keywords

Climate change $\cdot$ forest policy and practice $\bullet$ forest research $\bullet$ Irish forestry

\section{Background to forest research in Ireland}

Since the early $20^{\text {th }}$ century, Irish forest policy has focussed on the restoration of forest cover and considerable progress has been achieved; forest cover has increased from $1.5 \%$ of the land area in 1900 to $11 \%$ of the land area in 2020 . Early forestry establishment practice was informed by trial plantings, learned experiences and shared knowledge from Britain and Europe, the former whose programme shared many similarities with the Irish programme. The 1950s saw a rapid expansion in state planting, with national policy targets of 10,000 ha/yr. The demand for eligible land to support the new programme (land deemed unsuitable for productive agriculture) resulted in crops being planted on previously avoided areas (O'Carroll, 1962). In 1957, a research branch was established in the Department of Lands to provide technical information to assist the expanding state afforestation programme. The research branch had a mandate to conduct a forest inventory of state and private forests and included a soils and nutrition section whose work focussed on species selection, innovations in soil cultivation techniques and fertiliser application. Research into thinning and spacing of forest crops, forest genetics, forest pathology and vegetation control was added as the research branch became more established (Gallagher, 2021). Research into wood resource utilisation was conducted by the Forest Products Department of IIRS/Eolas/Forbairt based in Glasnevin in 1963. From this basis, the concept of career forest researchers working in specified areas was established and researchers became recognised national experts. From the mid-1970s to the mid-1980s, the research branch had 
42 permanent staff, 14 of whom were permanent researchers, 20 field foresters, 3 lab technicians and 5 support staff. In 1989, the forest enterprise and the research branch were vested in a newly established state forestry company, Coillte Teoranta. It focussed on operational research and tree improvement. In the 1990s, Coillte rearranged its research effort into five key areas: genetics and tree improvement; crop structure; silviculture; site studies; and forest protection. However, forest research effort was gradually phased out with tree improvement research and development continuing up until 2015. Early research was also conducted by An Foras Taluntais (now Teagasc) as part of the National Soil Survey (1958-1990) focussing on the capacity of Irish soils to grow various forest crops (Bulfin et al., 1973) and latterly research on the potential of farm forestry as a viable farming enterprise (Frawley \& Leavy, 2001).

In 1992, the National Council for Forest Research and Development (COFORD) was set up to coordinate national forest research and fund competitive research projects; this role was subsequently taken up by Department of Agriculture Food and the Marine (DAFM) in 2009 and remains part of the Firm/Stimulus/COFORD call for competitive research. The competitive call for proposals from COFORD has resulted in the emergence of forest research providing organisations (RPOs) at the third level (e.g. University College Dublin (UCD), National University of Ireland-Galway (NUIG), Waterford Institute of Technology (WIT), University College Cork (UCC), Trinity College Dublin (TCD), University of Limerick (UL)) and encouraged the increased involvement of Teagasc in contract forest research (Hendrick, 2017). Many of the outcomes of forestry research programmes have been incorporated into policy and practice (e.g. codes of forest practice, national forestry standard). In more recent years, research is reflecting the increasing awareness of the services provided by forests and there has been a growing awareness of the environmental role and impact of forests (Hendrick, 2010). The requirements to meet national and international commitments on climate change, biodiversity, water quality and forest health are becoming increasingly important drivers of forest policy (e.g. the Kyoto Protocol and the Paris Agreement). The European Green Deal (European Commission, 2019) also puts a focus on ensuring healthy and resilient forests so that they can contribute significantly to biodiversity and climate goals, reduce and mitigate natural disasters, while securing livelihoods and supporting a circular bioeconomy and rural communities. The role of research to address the potential negative impacts of climate change, increase sustainability and the circular bioeconomy is becoming increasingly important.

The objective of this paper is to provide the reader with an overview of forest research achievements across areas relating to forestry practice and policy covering the last $60 \mathrm{yr}$. The review is intended to provide the reader with a perspective on how the outcomes of research have informed policy and practice and the potential role of this and future research to assist in the achievement of sectoral targets and wider national and international goals.

\section{Establishing new forests}

Increasing forest cover is at the heart of current government policy to develop a competitive and sustainable forest sector and is central to the government's Climate Action Plan (DAFM, 2014; Anon, 2019a). Here, we look at research which may assist policy development in this area.

To achieve planting targets of $8,000 \mathrm{ha} / \mathrm{yr}$, additional land will be required to be planted; is this feasible? Farrelly \& Gallagher (2015a) identified an area of 3.75 million ha of land suitable for afforestation in Ireland, of which 1.3 million ha was classified as marginal agricultural land. In the 1980s, Bulfin (1987) performed a similar analysis and concluded that much of the marginal agricultural land had the potential for forestry to provide good yields over relatively short rotations, providing alternative sources of incomes for farmers. As a result, many farmers on marginal land availed of forestry grants and premiums to plant, particularly in the 1990s and 2000s, and many owners' forests have reached the final harvest age. The technical feasibility of planting land is well established and forms current operational practice (Forest Service, 2015). The outcomes of early research succeeded in providing guidelines to enable tree growth on a range of soils, with a limited history of agricultural usage (e.g. O'Carroll, 1962, 1975). However, as better land has been planted, opportunities to diversify species and plant broadleaves will require prior knowledge of the species site requirements. Much of the current knowledge base for species selection comes from practical research and development and uptake by state foresters, supplemented by knowledge of similar species and soils in the UK and wider afield. While disseminated within the state sector, many research outcomes were not formally published in peer-reviewed journals. Some of the results were synthesised in the COFORD book "A Guide to Species Selection" published in 2003 (Horgan et al., 2003).

Research into species selection can provide a deeper understanding of the cause-and-effect mechanisms that affect forest tree growth and yield, the aim being to predict the forest growth for investment decisions or to quantify the impact of climate change on the species growth (Farrelly et al., 2011). Vegetation and indicator species have been used to provide an indication of the inherent wetness and nutritional status of soils and their suitability for various tree species (Anderson, 1950). More recently, vegetation criteria have been used to provide an assessment of the eligibility of land for afforestation grant aid (Farrelly \& Gallagher, 2015b). 
To assess national and regional opportunities for afforestation, soil maps, such as those completed by the National Soil Survey (An Foras Taluntais 1958-1990; now Teagasc), can be used to assess the potential of forest tree species based on the occurrence of certain soil types (e.g. Conry \& Clinch, 1989). Advancements in geographic information systems (GIS) have used these principles to assess the suitability of Irish soils for forestry (Loftus et al., 2002). In recent years, more complex GIS modelling techniques incorporate multiple competing land use objectives to provide a more realistic assessment of the amount of land available for afforestation (Farrelly \& Gallagher, 2015a). The advent of climate change creates uncertainty in the current state of knowledge surrounding tree species selection and new research into the adaptive potential of key forest tree species to climate change in Ireland is necessary (Farrelly, 2021).

\section{Forest genetics and tree improvement}

Tree improvement is at the heart of increasing the competitiveness of the forest sector and offers the potential to increase carbon sequestration and harvest output. Here, we consider the advancements in tree breeding over the last $60 \mathrm{yr}$.

Tree improvement has been conducted in Ireland since the 1950s, with most of the early work focussing on provenance testing (Fennessy et al., 2012). Early provenance testing focussed on lodgepole pine (Pinus contorta Douglas), assessing provenances that offered a combination of acceptable yield and acceptable stem form (Pfeifer, 1993). In the 1960s and 1970s, an extensive provenance testing of Sitka spruce (Picea sitchensis (Bong.) Carr) took place. Results of the trials confirmed that selecting Sitka spruce origins from the southern part of its native range (Washington and Oregon) provided significant increases in productivity of up to one yield-class ( $2 \mathrm{~m}^{3} /$ ha per year) over conventional Queen Charlotte Island sources (Pfeifer, 1984). Based on these results, Coillte, the Irish Forestry Board, recommends the planting of Washington and north Oregon seed origins for all sites except those above $300 \mathrm{~m}$ and those that are susceptible to autumn frosts (Thompson et al., 2005). For some species, provenance selection may be the final step in the tree improvement process, mainly because further returns on any investment on breeding are likely to be low (or even negative) (O'Reilly et al., 2014). For Sitka spruce, an improvement programme has been in place since the 1970s and individuals (parents) have been selected for breeding based on their progeny achieving a $15 \%$ increase in height gain over an untested control (Thompson, 2013). Typically, parent trees are grafted and put into seed orchards to produce improved seed, and Coillte currently has seed orchards of Sitka spruce and Lodgepole pine, for use in its reforestation programme. Research as part of the DAFM FORM project focussed on developing methods for early selection of improved parents and assessment of the performance of full-sib families under drought conditions (Grant et al., 2016). More recently, the GeneSIS project hopes to evaluate the potential of using genomics and genomic selection tools to accelerate the Sitka spruce tree improvement programme (Farrelly et al., 2020). The research hopes to identify good parental combiners using genomic and progeny test data to develop a genomic prediction model; the aim is to reduce the time associated with progeny testing (often $15+\mathrm{yr}$ ). The impacts of the Sitka spruce improvement programme are estimated to generate a potential annual benefit of $€ 5.7$ million, assuming an annual planting programme of 9,000 ha/yr (O'Reilly et al., 2014).

Research into broadleaved tree improvement has been conducted by Teagasc since the late 1990s and is focussed on the development of a sustainable supply of improved, adapted and healthy seed and plant material to satisfy the European Union (EU) Forest Reproductive Material (FRM) regulations. The research to date has brought about the commercial supply of improved birch (Betula spp.) and alder (Alnus glutinosa L. Gaertn.) seed which is available to farmers and landowners wishing to plant broadleaves (Sheridan, 2021). Other research carried out as part of the DAFM FORM project seeks to select ash (Fraxinus excelsior L.) genotypes which show tolerance to the ash dieback disease (Hymenoscyphus fraxineus (T. Kowalski) Baral, Queloz \& Hosoya) and identify the primary method of infection of ash plants (NemesioGorriz et al., 2019). The research is focussed on identifying genotypes which show tolerance to the disease. Tolerant genotypes have been sourced after screening under high disease pressure in Lithuania, and others have been obtained by sourcing tolerant genotypes from European institutions. A gene bank of selected material has been established in Co. Kilkenny, and further research will continue to monitor which genotypes continue to show tolerance to the disease.

\section{Forest management}

The EU Green Deal (EC COM [2019] 640) and the New EU Forest Strategy for 2030 (European Commission, 2021) promotes the sustainable production of timber from wellmanaged forests. In the following section, we consider research in broadleaved management and timber forecasting.

\section{Broadleaved management}

The production of high-quality sawlog is dependent on timely management. A management intervention carried out decades prior to felling can have a large impact on whether the timber is high grade and suitable for sawlog, or low grade and suitable 
for firewood. Considerable loss of expertise in broadleaved management exists in Ireland; this can be traced back to the Industrial Revolution, when the importance of growing highquality stems for industrial needs was less important as iron and steel displaced many timber products (Bulfin \& Radford, 2001). Thus, the decline in management of broadleaves required research commensurate with the renewed interest in planting broadleaves. Early work in broadleaved management focussed on the establishment and management of broadleaf species to replace those cleared for fuel and food production during the Second World War for use as shelterbelts (Petrie, 1943). The growing of ash for hurley production was a subject of much research. Fitzsimons \& Luddy (1986) provided the silviculture prescriptions for growing of ash for hurley production, incorporating planting rate, fertiliser, protection from browsing and thinning. Other options for growing ash included the planting of ash in mixtures with silver fir (Abies alba Mill.), Norway spruce (Picea abies (L.) H. Karst.) or noble fir (Abies procera Rehder). The use of the mixture provided protection from frost and exposure and served to suppress ground vegetation and provided much-needed revenue in the early years through the sale of Christmas trees (Fitzsimons \& Luddy, 1986). Further research by Culleton \& Bulfin (1992) and Culleton et al. (1995) examined the impact of vegetation control on the early height growth of ash concluding that it was vital for rapid and consistent establishment. Research into the management of young broadleaved crops concluded the benefits of formative shaping - the pruning of young trees - with the objective of producing a single straight stem of at least $5 \mathrm{~m}$ in length with small branches that will quickly die at the onset of canopy closure leaving the bole virtually defect free (Kerr, 1992). Research conducted by Bulfin \& Radford (1998a, 1998b) on formative shaping on eight broadleaf species concluded that formative shaping improved stem form over that period and should commence ideally when the trees are $1.0-1.6 \mathrm{~m}$ in height. As better land was beginning to be planted by farmers in the early 1990s, COFORD published a book, "Growing Broadleaves" (Joyce et al., 1996), to assist practice development and an updated publication, "Broadleaf Forestry in Ireland" (Huss et al., 2016), which integrates forest research across soils, forest genetics, silviculture, forest growth and yield. More recent research has focussed on early tending and thinning of broadleaved crops and developing methods for rehabilitating poorly performing broadleaved stands where research is used to inform management practice (Short \& Hawe, 2012, 2018).

\section{Timber forecasting}

Efficient forest management requires estimates of stand development and productivity to enable forest managers to plan operations and arrange timber sales and for financial managers to forecast costs and revenue. The British Forestry Commission yield tables have traditionally been used for forecasting production in Irish stands since the first table was produced in 1953 (Hummel \& Christie, 1953). The yield tables are based on the yield class system (the maximum mean annual increment of a stand) and allow growth projections to be made following a prescribed management regime (Edwards \& Christie, 1981). While the range of yield classes available covered yield class 6-24 $\mathrm{m}^{3} /$ ha per year, early indications from assessments of the growth of Irish stands suggested that the yield classes in Ireland were often more than this range, owing to differences in growth rate, tree form and provenances grown in Ireland (Joyce \& O'Carroll, 2002). This precipitated the development of yield tables for lodgepole pine in 1966 (Gallagher et al., 1987). The increased use of mathematical models and, later, computers assisted developments in yield research as it allowed complex functions to be fitted to large datasets and provided flexibility to incorporate diverse management objectives which were not dependent on a defined course of management. As a result, dynamic yield models were developed for Sitka spruce, Norway spruce and Douglas fir (Pseudotsuga menziesii (Mirbel) Franco) (Broad \& Lynch, 2006), followed by the development of yield models for ash and Japanese larch (Larix kaempferi (Lamb.) Carr.) (McCullagh, 2013). The Irish dynamic yield models are available from COFORD as a software program called Growfor and are used primarily to assist the management of forest stands and produce forecasts for even-aged monospecies stands. Another yield model called Carbware has been developed for use in Irish forestry and has been used to assess carbon stocks in Irish forests (Hawkins \& Black, 2012). The Carbware model is a single-tree growth model that simulates carbon dynamics in the forest, is useful at the individual tree level and can be used for uneven-aged and mixed stands. Single-tree modelling is data intensive, requiring that each tree is measured, and data costs and computing time can be significantly greater than those of stand model approaches. Future research may require re-development of models to incorporate the impact of genetic improvement and climate change and their impact on the growth and yield of forest crops.

\section{Forest protection}

Ensuring healthy and resilient forests is central to the new EU forest strategy for 2030 (European Commission, 2021); in this section, we consider two areas where research can assist with these objectives, notably windblow and insect pests and diseases.

\section{Windblow}

Given the climate and historical trends in planting, it is not surprising that the most significant abiotic factor causing 
damage to forests in Ireland is wind. Climate change is expected to bring about an increase in the frequency and intensity of winter storms in Ireland (Ní Dhubháin \& Farrelly, 2018). Wind causes trees to be uprooted (windthrow) or break (windsnap), leading to significant financial losses for forest owners (Nieuwenhuis \& Fitzpatrick, 2002). The impact of these storms can also result in the provision of ideal breeding grounds for insects and fungi (Peltola, 2006). Research has shown that management of forests, particularly on poorly drained soils, can result in the onset of windblow. In a survey of research plots by Gallagher (1974), those which had been unthinned suffered less damage than thinned plots. In a study of forests in Northern Ireland, the effect of altitude, soil type, and aspect were factors linked to increased windblow with high elevation sites, planted on gleyed soils on windward slopes, being more vulnerable to windblow (O'Cinneide, 1974). Hendrick (1989) and Rodgers et al. (2006) investigated the impact of site cultivation methods on tree stability and concluded that the force required to overturn trees planted on mole drains was greater than those planted where furrow ploughing had been used.

Useful tools have been developed to assist forest managers to quantify the risk of windblow. Ní Dhubháin et al. (2001, 2009) produced a model to predict the probability of windthrow risk in Sitka spruce stands based on site and crop factors. The model requires the height of the forest (risk increases as height increases), thinning status (thinning increases risk), soil type (risk is higher on poorly drained soils) and site elevation (risk increases with increasing elevation). Future research should build on established research and focus on methods for mitigating risk, especially as the frequency of winter storms is expected to increase. Forest management operations and those which predispose forest stands to windblow need further study (Ní Dhubháin \& Farrelly, 2018).

\section{Insect pests and diseases}

In the 1950s, a strategic forest protection research programme was set up by the research branch of the Forest Service. Early work included an investigation into pine shoot dieback (putatively linked to Pullularia pullulans (de Bary) G. Arnaud) (de Brit, 1967) and group dieback (causal agent Rhizina undulata Fr.) of conifers (McKay \& Clear, 1955). Research into the ongoing threat of fungal pathogens such as Heterobasidion annosum (Fr.) Bref. which caused heart rot of many forest species was conducted by McAree (1975) and subsequent control resulted in the use of urea on tree stumps to promote the growth of saprophytic fungi and limit the opportunities for the spread of the pathogen. Often collaborative work with the UK facilitated the quick discovery of pathogens and surveys for Dutch elm disease (Ophiostoma ulmi (Buisman) Melin \& Nannf.) in Ireland (Mangan \& Walsh, 1980) were conducted after it had been discovered on elm
(Ulmus glabra Huds.) several years earlier in Britain. It is likely that the increase in the numbers of threatening nonnative pests and pathogens being detected in Ireland can be linked to imports of lumber and wood packaging material as far back as the 1970s (e.g. O'Connor \& Nash, 1979). In 1977, the first species-specific horizon scans for current and future pest threats were carried out for Sitka spruce (de Brit \& McAree, 1977). Extensive work has also been done on control methods for the large pine weevil (Hylobius abietis L.) (e.g. Dillon et al., 2006); however, the pest remains a serious issue on reafforestation sites and control measures are becoming more difficult as pesticide options are becoming more limited. The outbreak of Phytophthora ramorum Werres, De Cock \& Man in 't Veld. in Japanese larch provided insights into the pathogen behaviour and efficient controls (O'Hanlon et al., 2017). The ash dieback epidemic has resulted in research to understand the epidemiology of the pathogen (Burns et al., 2017) and more latterly to understand optimal ways to control the disease and in the selection of tolerant genotypes (DAFM funded FORM and NEXCELSIOR projects).

The FORM project provided additional horizon scanning and pest risk assessment research findings for the benefit of Irish forestry (Truffen \& Grogan, 2018). Preventative research through EU and the European and Mediterranean Plant Protection Organisation Pest Risk Assessments has succeeded in identifying over 200 EU-regulated pests and pathogens and protected zones to exclude pests indigenous to Europe from areas they are not already present. Routine surveys and protective measures are being implemented to prevent establishment of such pests in Ireland (Anon, 2019b) and updates to the regulated lists are recommended as research progresses (Anon, 2019c).

\section{Forestry and carbon}

Ireland's commitment to emission reduction under the Kyoto Protocol (UNFCC, 1997) and Paris Agreements (United Nations, 2015) has resulted in significant research effort to provide increased knowledge about the carbon balance in forest ecosystems.

Research into forest carbon sequestration of Irish forests began to be funded by COFORD in the early 2000s, beginning with the CARBiFOR project (Black \& Farrell, 2006). Research focussed on improving inventory-based estimates of forest carbon sequestration in the most commonly occurring Sitka spruce dominated forest type in Ireland. An ecosystem approach was used to examine stocks and fluxes between the soil, tree and ground debris/vegetation pools. Biometric inventories of chronosequence sites were used with biomass models to estimate tree biomass and carbon accumulation 
(Tobin \& Nieuwenhuis, 2007). Deadwood (Tobin et al., 2007) stocks were also examined, as were soil (Saiz et al., 2007) and tree respiration. Eddy covariance measurements from a core research site (Dooary, Co. Laois) were used to estimate the net ecosystem exchange, which was used to validate estimates made based on inventory-based measurements (Black et al., 2009). The research was instrumental in determining that over the first Kyoto commitment period from 2008 to 2012, annual sequestration rates were higher than previously reported (4-8 t C/ha per year compared to $3.36 \mathrm{t} \mathrm{C/ha} \mathrm{per}$ year as reported by Kilbride et al. (1999). Research included the development of a national accounting software system for forestry called CARBWARE (Hawkins \& Black, 2012) which estimated that Irish forests sequestered $17 \mathrm{Mt} \mathrm{CO}_{2}$ eq. during the period $2008-2012$, representing $20 \%$ of Ireland's national greenhouse gas emissions reduction target for the period (Black et al., 2012).

Further research by Saunders et al. (2012) reported a climate-dependent impact of thinning on forest carbon uptake. Higher air temperatures and solar radiation in the growing season following the thinning were responsible for an immediate compensatory increase in photosynthesis by the remaining trees. Forest soil carbon stocks have been investigated by Wellock et al. (2011b), who found that the afforestation resulted in no significant changes in soil carbon, citing the high degree of uncertainty arising from a low sampling number. For the estimation of peat soil stocks, Wellock et al. (2011a) found peat depth and type to be significant factors. Byrne \& Milne (2006) found that the afforestation of peat soils resulted in net emissions of carbon, but this finding depended heavily on a range of assumptions regarding the rate of peat carbon loss. However, Byrne \& Farrell (2005) demonstrated that losses due to afforestation of blanket peat soils could be compensated by carbon taken up by tree growth. However, the difficulties presented by the drying of such large carbon stores by forests growing on peat soils, as anticipated by Farrell \& Boyle (1990) and Tomlinson (2005), will continue to be a challenge for future management in light of expected changes in climate (Jovani-Sancho et al., 2021).

\section{Forestry economics}

Early economic research focused on qualitative analysis of planting policy with reference to the area planted (Attwood, 1964) and critiques of the poor quality of the land being acquired for planting by the state. Given the focus on increasing afforestation rates, it is not surprising that the comparison of agriculture and forestry in terms of land use change is a frequent point of discussion in the early literature (Clear, 1948), later analysed in detail in Frank Convery's work
(1973). Other early topics of interest included assessing the wider benefits of the forest estate in relation to its economic value (Durand, 1992) and the social impact of forestry (Convery, 1970; Clinch, 2000). Research into the economics of crop types was conducted for lodgepole pine (O'Driscoll, 1980) and Sitka spruce (O'Brien, 1986). The economics of timber production and the relative merits of management operations such as spacing and re-spacing to improve returns were studied by O'Brien (1981) and the economic merits of thinning by Gerely \& Phillips (1999). The 1970s and the oil crisis saw research into the economics of wood energy (Neenan, 1977) and short rotation forestry (Neenan \& Lyons, 1981). Research into the timber processing sector was also conducted to include sawmilling and the economy by Convery (1981), while Anderson et al. (1994) examined the wood processing and forest products wood chain.

The 1970s and 1980s saw early research into biodiversity (Long \& Whelan, 1984), and recreation economics were examined by Murphy \& Gardiner (1983). Later studies of the ecosystem services provided by forests included the "tourists" perception of the landscape (O'Leary et al., 1998), forests and water quality (Kelly-Quinn et al., 1997), the role of forest carbon sequestration (Hendrick \& Ryan, 2001) and the amenity value of forests (Hynes et al., 2007). Bullock et al. (2016) undertook a comprehensive review of ecosystem services and their valuation, while more recently, Duffy et al. (2020) examined the impact on water quality of agriculture replacing forests.

Research into the factors influencing planting accompanied the rapid uptake of forestry grants by farmers (e.g. Ní Dhubháin \& Gardiner, 1994; Ní Dhubháin, 1995; McCarthy et al., 2003). However, as planting rates began to decline in the 2000s, research into the barriers to farmer planting was initiated. McDonagh et al. (2011) found that the most important barrier to afforestation was that farmers needed their land for agriculture and the permanent nature of the planting decision. The relativity of agricultural and forest incomes was investigated by Behan \& McQuinn (2005), while Ryan et al. (2017) investigated the impact of taxation and benefits. Duesberg et al. (2013) undertook qualitative analyses to provide more nuanced information on farmers' attitudes to forestry that concurred with findings from a detailed farm-level quantitative analysis (Ryan et al., 2018), namely that while financial drivers are important, other factors such as nonpecuniary benefits (Howley et al., 2015) are also important drivers or barriers to land use change.

\section{Discussion and conclusion}

It is sometimes stated that research meets society's needs only when it contributes to policy aims being met. However, 
research also has a role in ensuring that policy goals are well founded, so research must inform policymakers, as well as practitioners, through scientific, timely and effectively communicated information. This review is intended to give a perspective on some of the outcomes of forestry research over the last $60 \mathrm{yr}$ and how many have been taken up in policy and practice (e.g. Code of practice and Forestry Standards Manual [Forest Service, 2000, 2015]). Perhaps the most important goal commensurate with forest policy is to increase forest cover. Recent low planting levels suggest that there is an uncertainty as to whether goals and targets can be achieved. The outputs of research have informed afforestation scenario modelling and had a significant impact in providing input to forest policy development and public discourse on forestry in relation to economic impact of forestry. To achieve desired afforestation targets, the work of Farrelly \& Gallagher (2015a) suggests that in principle sufficient land resources exist to increase forest cover, while the research of Ryan et al. (2018) suggests that considerable effort will be required to initiate future land use change, perhaps requiring a deeper understanding of the drivers of land use change. The incorporation of behavioural economics, particularly in relation to long-term decisions and attitudes associated with afforestation, is necessary. The importance of carbon as an ecosystem service is a key driver, and further research in relation to its implications for carbon policy needs to be conducted. The role of harvested wood products in carbon sequestration and the circular economy will only increase in importance.

Research in forest establishment, particularly on the nutrition of forest crops (e.g. O'Carroll, 1975), did much to enable tree growth on a range of soils associated with early state afforestation which was confined to marginal and submarginal soils to avoid competition with agriculture (Gray, 1964). This research contributed significantly to continuing wood production and harvest on these soils. Research on species selection synthesised in the book by Horgan et al. (2003) has been instrumental in informing the Forest Service, who use it to inform the list of approved species and provenances for afforestation. The benefits of various tree improvement programmes are currently being realised with the availability of improved seed for various tree species (e.g. Thompson, 2013). The outcomes of this research will play a key role to increase carbon sequestration, improving the quality of timber products from forests and increasing the competitiveness of the forest sector. The uncertainties posed by climate change are creating uncertainties in Irish forestry. Increasing the knowledge base of how tree species respond to climatic stresses will become increasingly important to evaluate tree planting decisions to promote forest health and resilience of the resource (Farrelly, 2021).
Forest management decisions have been assisted by the development of Growfor, a dynamic yield model for forest management which has been the outcome of much research into crop growth and yield (e.g. Broad \& Lynch, 2006) and is widely used within the forest sector to forecast future growth and yield of stands and the likely impact of management interventions on crop development.

Methods to mitigate the risk of windblow will be necessary which may include alternative management strategies, these will require further research (Ní Dhubháin \& Farrelly, 2018). To assist the development of broadleaved silviculture which was lacking, many research outcomes on soils, forest genetics, silviculture and forest growth and yield have been incorporated into two significant publications on practice - Growing Broadleaves (Joyce et al., 1996) and Broadleaf Forestry in Ireland (Huss et al., 2016) which serve as important reference guides for broadleaved forest management.

The significant afforestation programme in Ireland over the last two decades has resulted in the sequestration of a large quantity of atmospheric carbon. Research to quantify the carbon resource (e.g. CARBiFOR) has been instrumental in assisting the development of a national greenhouse gas accounting system to UNFCCC to Tier 2 and Tier 3 levels which is used for national reporting. However, the management of this carbon store and the forest resource has acquired a consequent responsibility. The impact of disturbances caused by management interventions such as thinning and clearfelling operations, as well as abiotic factors such as fire and wind and biotic factors, has a consequence for greenhouse gas dynamics in forests. It is essential therefore to maintain long-term forest monitoring datasets, where both biometric and flux measurements can be directly associated with climatic factors. Opportunity for the combined use of remote sensing with inventory measurements to monitor changes in forest health and aboveground carbon mass may assist the process (Mclnerney et al., 2011). The continued provision of ecosystem services requires that the resource is adequately protected. Some of the outcomes of forest protection research have been incorporated into advice and practice, notably in pine weevil control and the Forest Service schemes to control and replace Chalara-infected stands. New research into the basic biology of forest pests is necessary. Further research into pre-emptive methods and pest risk analysis (e.g. Truffen \& Grogan, 2018) will be necessary to be better prepared for biotic challenges.

\section{Acknowledgements}

The authors would very much like to thank Dr. Gerhardt Gallagher for providing background information on the 
activities of Research Branch, Department of Lands. We would also like to thank an anonymous reviewer whose suggestions have succeeded in improving the article. Thanks also to Oliver Sheridan for an update on the status of the Teagasc birch and alder improvement programme.

\section{References}

Anderson, M.L. 1950. The selection of tree species. In: "An Ecological Basis of Site Classification for Conditions Found in Great Britain and Ireland", 1st Edition, Oliver and Boyd, Edinburgh and London, UK.

Anderson, C., Thomson, K. and Psaltopoulos, D. 1994. Wood processing in the Irish Republic: a survey report. Irish Forestry 51: 27-33.

Anon. 2019a. Climate Action Plan 2019. Department of the Environment, Climate and Communications. Dublin 2. Available online: https://assets.gov.ie/10206/d042e174c1654c6ca14f39242 fb07d22.pdf. Accessed 2 December 2021.

Anon. 2019b. Commission Implementing Regulation (EU) 2019/2072 of 28 November 2019 establishing uniform conditions for the implementation of Regulation (EU) 2016/2031 of the European Parliament and the Council. Available online: https://eur-lex.europa. eu/legal-content/EN/TXT/PDF/?uri=CELEX:32019R2072\&from=EN. Accessed 8 December 2021.

Anon. 2019c. Annual Report and Council Recommendations 2019. EPPO Bulletin 50: 578-594.

Attwood, E.A. 1964. Problems of forestry development in Ireland. Irish Forestry 21: 49-57.

Behan, J. and McQuinn, K. 2005. Farm forestry in Ireland. Irish Forestry 62: 58-72.

Black, K. and Farrell, E.P. (eds). 2006. "Carbon Sequestration in Irish Forest Ecosystems", COFORD, Dublin.

Black, K., Byrne, K.A., Mencuccini, M., Tobin, B., Nieuwenhuis, M., Reidy, B., Bolger, T., Saiz, G., Green, C., Farrell, E.T. and Osborne, B. 2009. Carbon stock and stock changes across a Sitka spruce chronosequence on surface-water gley soils. Forestry $\mathbf{8 2}$ : 255-272.

Black, K., Hendrick, E., Gallagher, G. and Farrington, P. 2012. Establishment of a national projected reference level for forest management for the period 2013-2020 under Article 3.4 of the Kyoto Protocol. Irish Forestry 69: 7-32.

Broad, L. and Lynch, T. 2006. Growth models for Sitka spruce in Ireland. Irish Forestry 63: 53-79.

Bulfin, M. 1987. Availability of land for forestry in Ireland and its suitability for Sitka spruce. Irish Forestry 44: 18-31.

Bulfin, M. and Radford, T. 1998a. Effect of early formative shaping on newly planted broadleaves. Part 1: Quality. Irish Forestry 55: 35-51.

Bulfin, M. and Radford, T. 1998b. Effect of early formative shaping on newly planted broadleaves-Part 2: height and diameter growth. Irish Forestry 55: 52-61.
Bulfin, M. and Radford, T. 2001. A review of historical literature on the pruning (formative shaping) of broadleaved trees from the sixteenth to the nineteenth century. Irish Forestry 58: 30-45.

Bulfin, M., Gallagher, G. and Dillon, J. 1973. Forest production. In: "County Leitrim resource Survey, Part 1 - Land Use Potential (Soils, Grazing Capacity and Forestry)", Soil Survey Bulletin 29, An Foras Talúntais (now Teagasc), Oakpark, County Carlow, Ireland, pages 49-56.

Bullock, C.H., O'Callaghan, C., Dhubháin, Á.N., Iwata, Y., O'Donoghue, C., Ryan, M. and Kelly-Quinn, M. 2016. A review of the range and value of ecosystem services from Irish forests. Irish Forestry 73: 65-95.

Burns, P., Gilligan, C., Castle, M., Nieuwenhuis, M. and Yearsley, J. 2017. "Modelling the Airborne Spread of Ash Dieback Disease", Final report to DAFM. Agriculture House, Dublin 2.

Byrne, K.A. and Farrell, E.P. 2005. The effect of afforestation on soil carbon dioxide emissions in blanket peatland in Ireland. Forestry 78: 217-227.

Byrne, K.A. and Milne, R. 2006. Carbon stocks and sequestration in plantation forests in the Republic of Ireland. Forestry 79: 361-369.

Clear, T. 1948. Does our forest policy need an overhaul? Irish Forestry 4: $49-58$

Clinch, J.P. 2000. Assessing the social efficiency of temperate-zone commercial forestry programmes: Ireland as a case study. Forest Policy and Economics 1: 225-241.

Conry, M.J. and Clinch, P. 1989. The effect of soil quality on the yield class of a range of forest species grown on the Slieve Bloom Mountains and foothills. Forestry 62: 297-497.

Convery, F. 1970. Forestry and Irish economic and social development. Irish Forestry 27: 52-67.

Convery, F.J. 1973. Rural land use and the balance of payments. Irish Forestry 30: 4-15.

Convery, F.J. 1981. The native sawmilling industry and Irish forestry. Sawmilling and the economy. Irish Forestry 38: 78-91.

Culleton, N. and Bulfin, M. 1992. Effects of weed and grass control on the establishment of Fraxinus excelsior L. Irish Forestry 49: $55-60$.

Culleton, N., Murphy, W.E. and Hicks, R.R. 1995. Competition control for establishment of ash (Fraxinus excelsior L.) on lowland soil in Ireland. Irish Forestry 52: 88-94.

DAFM. 2014. "Forests, Products and People. Ireland's Forest Policy A Renewed Vision", Department of Agriculture Food and the Marine, Dublin.

de Brit, G. 1967. Forest protection. In: "Forest Research Review 19571964". Department of Lands, Ireland.

de Brit, G. and MCAree, D. 1977. Pests and diseases of Sitka spruce. Irish Forestry 34: 22-30.

Dillon, A.B., Ward, D., Downes, M.J. and Griffin, C.T. 2006. Suppression of the large pine weevil Hylobius abietis (Coleoptera: Curculionidae) in pine stumps by entomopathogenic nematodes with different foraging strategies. Biological Control 38: 217-226. 
Duesberg, S., O'Connor, D. and Ní Dhubháin, A. 2013. To plant or not to plant-Irish farmers' goals and values with regard to afforestation. Land Use Policy 32: 155-164.

Duffy, C., O’Donoghue, C., Ryan, M., Kilcline, K., Upton, V. and Spillane, C. 2020. The impact of forestry as a land use on water quality outcomes: an integrated analysis. Forest Policy and Economics 116: 102-185.

Durand, J. 1992. Building a national resource fifty years of Irish forestry. Irish Forestry 49: 1-9.

Edwards, P.M. and Christie, J.M. 1981. Yield models for forest management. Forestry Commission Booklet 48: 48.

European Commission. 2019. The European Green Deal. Communication from the Commission to the European Parliament, the European Council, the Council, the European Economic and Social Committee and the Committee of the Regions. COM (2019) 640 final. Available online: https://eurlex. europa.eu/resource.html?uri=cellar:b828d1651c22-11ea-8c1f-01aa75ed71a1.0002.02/DOC_1\&format=PDF. Accessed 3 December 2021.

European Commission. 2021. New EU Forest Strategy for 2030. Communication from the Commission to the European Parliament, the Council, the European Economic and Social Committee and the Committee of the Regions. COM (2021) 572 final. Available online: https://eur-lex.europa.eu/resource.html?uri=cellar:0d918e07e610-11eb-a1a5-01aa75ed71a1.0001.02/DOC_1\&format=PDF.

Farrell, E. and Boyle, G. 1990. Peatland forestry in the 1990s. 1. Lowlevel blanket bog. Irish Forestry 47: 69-78.

Farrelly, N. 2021. FitForests - Ensuring Correct Tree Species Choice to Address Climate Change Uncertainties. Available online: https://www.teagasc.ie/news--events/daily/forestry/fitforestsensuring-correct-tree-species-choice-to-address-climate-changeuncertainties.php [Accessed 2 June 2021].

Farrelly, N. and Gallagher, G. 2015a. The potential availability of land for afforestation in the Republic of Ireland. Irish Forestry 72: 120-138.

Farrelly, N. and Gallagher, G. 2015b. The development of a site classification for Irish forestry - Irish Forestry. Irish Forestry $\mathbf{7 2}$ : 166-188.

Farrelly, N., Ní Dhubháin, Á. and Nieuwenhuis, M. 2011. Site index of Sitka spruce in relation to different measures of site quality in Ireland. Canadian Journal of Forest Research 41: 265-278.

Farrelly, N., Tobin, B., Cashell, R. and Zang, S. 2020. The application of genomics to Sitka spruce tree improvement. Forestry \& Energy Review. Autumn/Winter 2020. 10: 44-48.

Fennessy, J.F., Doody, P. and Thompson, D. 2012. A review of tree improvement programmes in Ireland - historical developments, current situation and future perspective. Irish Forestry 69: 184-203.

Fitzsimons, B. and Luddy, W.B. 1986. Growing ash for hurleys. Irish Forestry 43: 32-55.

Forest Service. 2000. "Code of Best Forest Practice". Forest Service, Department of the Marine and Natural Resources, Dublin.

Forest Service. 2015. "Forestry Standards Manual". Forest Service, Department of Agriculture, Food and the Marine, Dublin.
Frawley, J.P. and Leavy, A. 2001. "Farm Forestry: Land Availability, Take-Up Rates and Economics", Teagasc.

Gallagher, G.J. 1974. Windthrow in state forests in the republic of Ireland. Irish Forestry 31: 154-167.

Gallagher, G.J. 2021. Personal communication.

Gallagher, G.J., Lynch, T.J. and Fitzsimons, B. 1987. Lodgepole pine in the Republic of Ireland II. Yield and management of coastal lodgepole pine. Forest Ecology and Management 22: 185-203.

Gerely, F. and Phillips, H. 1999. Thinning practices and economics, Hungary and Ireland compared. In: "The Thinning Wood Chain". Proceedings of a IUFRO (Research Unit 3.09. 00) Conference on Harvesting and Economics of Thinnings, Ennis, Ireland, 4-7th May 1999. National Council for Forest Research and Development (COFORD), pages 86-94.

Grant, O., Monterro Ribero, A.F., Glombick, P. and O'Reilly, C. 2016. Impact of limited water availability on a range of full-sibling Sitka spruce (Picea sitchensis (Bong.) Carr.) families. Forestry 91: 83-97.

Gray, H.J. 1964. The economics of Irish forestry - Dublin. Journal of the Statistical and Social Inquiry Society of Ireland XXI: Part II, 1963/1964, 18-44.

Hawkins, M. and Black, K. 2012. Single tree growth models for Irish forestry. Irish Forestry 69: 33-49.

Hendrick, E. 1989. The effect of cultivation method on the growth and root anchorage of Sitka spruce. Irish Forestry 46: 19-28.

Hendrick, E. 2010. Forest research for 21st century Ireland - meeting society's needs. Irish Forestry 67: 107-123.

Hendrick, E. 2017. "Forest Research in Ireland - Historical Perspective, Current Position". COFORD Council - Long-Term Forest Research - Key Stakeholder Needs Workshop, Backweston Laboratory, Celbridge, Co. Kildare, 25 September 2017.

Hendrick, E. and Ryan, M. 2001. Carbon sequestration. Policy, science and economics. Proceedings of a COFORD seminar on Carbon Sequestration and Irish Forests, Dublin, Ireland, June 15th 2000.

Horgan, T., Keane, M., McCarthy, R., Lally, M. and Thompson, D. 2003. In: "A Guide to Forest Tree Species Selection and Silviculture in Ireland" (ed. J. O'Carroll), COFORD, Dublin, Ireland.

Howley, P., Buckley, C., Donoghue, C.O. and Ryan, M. 2015. Explaining the economic 'irrationality' of farmers' land use behaviour: the role of productivist attitudes and non-pecuniary benefits. Ecological Economics 109: 186-193.

Hummel, F. and Christie, J.M. 1953. Revised yield table for conifers in Great Britain. Forestry Commission Forest Record 24.

Huss, J., Joyce, P.M., MacCarthy, R. and Fenessy, J. 2016. "Broadleaf Forestry in Ireland". COFORD, Department of Agriculture, Food and the Marine, Dublin 2.

Hynes, S., Cahill, B. and Dillon, E. 2007. Estimating the amenity value of Irish woodlands. Irish Forestry 64: 17-31.

Jovani-Sancho, A.J., Cummins, T. and Byrne, K.A. 2021. Soil carbon balance of afforested peatlands in the maritime temperate climatic zone. Global Change Biology 27: 1-18. 
Joyce, P. and O'Carroll, N. 2002. "Sitka Spruce in Ireland". COFORD, Dublin.

Joyce, P.M., Huss, J., McCarthy, R., Pfeifer, A. and Hendrick, E. 1996. "Growing Broadleaves - Silvicultural guidelines for Ash, Sycamore, Wild Cherry, Beech and Oak in Ireland". COFORD, Dublin.

Kelly-Quinn, M., Tierney, D. and Bracken, J.J. 1997. "A Study of the Effects of Stream Hydrology and Water Quality in Forested Catchments on Fish and Invertebrates", AQUAFOR Report Volume 3, Stream Chemistry, Hydrology and Biota, Wicklow region. COFORD, Dublin, Ireland.

Kerr, G. 1992. Formative pruning. Forestry and British Timber 21: 26-28.

Kilbride, C.M., Byrne, K.A. and Gardiner, J.J. 1999. "Carbon Sequestration and Irish Forests". COFORD, Dublin, 37 pages.

Loftus, M., Bulfin, M., Farrelly, N., Fealy, R., Green, S., Meehan, R. and Radford, T. 2002. The Irish Forest Soils project and its potential contribution to the assessment of biodiversity. Proceedings of the Royal Irish Academy, Dublin, 102B, pages 151-165.

Long, P.A. and Whelan, J. 1984. The economics and management of the forest habitat for pheasants. Irish Forestry 42: 84-98.

Mangan, A. and Walsh, P.F. 1980. Some observations on the spread of Dutch Elm Disease in Ireland, 1978-79. Irish Journal of Agricultural Research 19: 133-140.

McAree, D.T. 1975. Fomes annosus - a forest pathogen. Irish Forestry 32: 118-128.

McCarthy, S., Matthews, A. and Riordan, B. 2003. Economic determinants of private afforestation in the Republic of Ireland. Land Use Policy 20: 51-59.

McCullagh, A. 2013. Development of dynamic yield models for conifers, broadleaves and mixtures in Ireland. PhD (Forestry) thesis, University College Dublin.

McDonagh, J., Farrell, M., Mahon, M. and Ryan, M. 2011. New opportunities and cautionary steps? Farmers, forestry and rural development in Ireland. European Countryside 2: 236-251.

McInerney, D., Suarez, J. and Nieuwenhuis, M. 2011. Extending forest inventories and monitoring programmes using remote sensing: a review. Irish Forestry 68: 6-22.

McKay, R. and Clear, T. 1955. A further note on group dying of Sitka spruce and Rhizina inflata. Irish Forestry 12: 58-63.

Murphy, W. and Gardiner, J.J. 1983. Forest recreating economics. Irish Forestry 40: 12-19.

Neenan, M. 1977. Prospects for energy from biomass in Ireland. Prospects for energy from biomass in Ireland. An Foras Taluntais, Dublin, Ireland, pp. 43-62.

Neenan, M. and Lyons, G. 1981. Short rotation forestry as a source of energy. In: "Energy from Biomass", 1st EC Conference, Applied Science Publishers, pages 232-238.

Nemesio-Gorriz, M., McGuinness, B., Grant, J., Dowd, L. and Douglas, G.C. 2019. Lenticel infection in Fraxinus excelsior shoots in the context of ash dieback. Forest - Biogeosciences and Forestry 12: 160-165.

Ní Dhubháin, Á.N. 1995. The impact of forestry on rural communities. Irish Forestry 52: 31-40.
Ní Dhubháin, Á. and Farrelly, N. 2018. "Understanding and Managing Windthrow", COFORD Connects, Silviculture/Management No. 23, COFORD.

Ní Dhubháin, Á.N. and Gardiner, J. 1994. Farmers' attitudes to forestry. Irish Forestry 5: 21-26.

Ní Dhubháin, Á., Bulfin, M., Keane, M., Mills, P. and Walshe, J. 2009. The development and validation of a windthrow probability model for Sitka spruce in Ireland. Irish Forestry 66: 74-84.

Ní Dhubháin, Á., Walshe, J., Bulfin, M., Keane, M. and Mills, P. 2001. The initial development of a windthrow risk model for Sitka Spruce in Ireland. Forestry 74: 161-170.

Nieuwenhuis, M. and Fitzpatrick, P.J. 2002. As assessment of stem breakage and the reduction in timber value and value recovery resulting from a catastrophic storm: an Irish case study. Forestry, 75: 513-523.

O'Brien, D. 1981. Economics of spacing, respacing and thinning. Irish Forestry 37: 77-96.

O'Brien, D.O. 1986. A financial appraisal of Sitka spruce. Irish Forestry 43: $128-141$.

O'Carroll, N. 1962. The progress of peatland afforestation in the Republic of Ireland. Irish Forestry 19: 93-101.

O'Carroll, N. 1975. "Fertiliser Prescriptions", 2nd Edition, Research Communication No 13, Forest and Wildlife Service (now Coillte), Newtownmountkennedy, County Wicklow, Ireland.

O'Cinneide, M.S. 1974. Quantitative assessment of the relative important and cooperative effects of factor influencing forest instability. Irish Forestry 31: 135-144.

O'Connor, J.P. and Nash, R. 1979. Record of six insect species (Coleoptera: Orthopetra) recently imported into Ireland. Irish Naturalists' Journal 19: 433-434.

O'Driscoll, J. 1980. The importance of lodgepole pine in Irish forestry. Irish Forestry 37: 7-22.

O'Hanlon, R., Choiseul, J., Grogan, H. and Brennan, J.M. 2017. In-vitro characterisation of the four lineages of Phytophthora ramorum. European Journal of Plant Pathology 147: 517-525.

O'Leary, T.N., McCormack, A.G. and Clinch, J.P. 1998. Tourists' perceptions of forestry in the Irish landscape-an initial study. Forest \& Landscape Research 1: 473-490.

O'Reilly, C., Phillips, H. and Thompson, D. 2014. A cost benefit analysis of tree improvement in Ireland. Irish Forestry 71: 113-131.

Peltola, H. 2006. Mechanical stability of trees under static loads. American Journal of Botany 93: 1501-1511.

Petrie, S. 1943. A plea for shelter-belts of broad-leaved trees. Irish Forestry 1: 16-19.

Pfeifer, A. 1984. Sitka spruce provenances in Ireland Results to 9 years. Proceedings of IUFRO International Sitka spruce Provenance Experiment, Edinburgh, Scotland, 1984, pages 151-164.

Pfeifer, A.R. 1993. Lodgepole pine IUFRO Provenances in Ireland: summary of results to 9 years. In: "Pinus contorta - From Untamed Forest to Domesticated Crop", Volume 11 (ed. D. Lindgren), Swedish University of Agricultural Sciences Report, pages 194-208. 
Rodgers, M., McHale, J. and Mulqueen, J. 2006. Stability of Sitka spruce on mole-drained and ploughed surface water gley soil. Irish Forestry 63: 37-52.

Ryan, M., O'Donoghue, C. and Kinsella, A. 2017. The potential impact of differential taxation and social protection measures on farm afforestation decisions. Irish Forestry 74: 99-129.

Ryan, M., O'Donoghue, C. and Hynes, S. 2018. Heterogeneous economic and behavioural drivers of the farm afforestation decision. Journal of Forest Economics 33: 63-74.

Saiz, G., Black, K., Reidy, B., Lopez, S. and Farrell, E. 2007. Assessment of soil $\mathrm{CO} 2$ efflux and its components using a process-based model in a young temperate forest site. Geoderma 139: 79-89.

Saunders, M., Tobin, B., Black, K., Nieuwenhuis, M. and Osborne, B. 2012. Carbon sequestration by a Sitka spruce forest is not compromised by thinning management. Agricultural and Forest Meteorology 157: 1-10.

Sheridan, O. 2021. Birch and Alder Seed Orchards in Teagasc. Available online: https://www.teagasc.ie/news--events/daily/ forestry/seed-orchards-.php [Accessed 2 June 2021].

Short, I. and Hawe, J. 2012. Possible silvicultural systems for use in the rehabilitation of poorly performing pole-stage broadleaf stands-Coppice-with-standards. Irish Forestry 69: 148-166.

Short, I. and Hawe, J. 2018. Ash dieback in Ireland - a review of European management options and case studies in remedial silviculture. Irish Forestry 75: 44-72.

Thompson, D. 2013. Development of improved Sika spruce for Ireland. Irish Forestry 70: 106-118.
Thompson, D., Lally, M. and Pfeifer, A. 2005. Washington, Oregon or Queen Charlotte Islands? Which is the best provenance of Sitka spruce (Picea sitchensis) for Ireland? Irish Forestry 62: 19-34.

Tobin, B. and Nieuwenhuis, M. 2007. Biomass expansion factors for Sitka spruce (Picea sitchensis (Bong.) Carr.) in Ireland. European Journal Forest Research 126: 189-196.

Tobin, B., Black, K., McGurdy, L. and Nieuwenhuis, M. 2007. Estimates of decay rates of components of coarse woody debris in thinned Sitka spruce forests. Forestry 80: 455-469.

Tomlinson, R.W. 2005. Soil carbon stocks and changes in the Republic of Ireland. Journal of Environmental Management 76: 77-93.

Truffen, M. and Grogan, H. 2018. Current, emerging and potential pest threats to Sitka spruce plantations and the role of pest risk analysis in preventing new pest introductions to Ireland. Forestry 92: $26-41$.

UNFCC. 1997. "Kyotos Protocol to the United Nations Framework Convention on Climate Change", Conference of the parties, Kyoto, 1-10 December 1997. Available online: https://unfccc.int/sites/ default/files/resource/docs/cop3/l07a01.pdf.

United Nations. 2015. "Paris Agreement". Available online: https:// unfccc.int/sites/default/files/english_paris_agreement.pdf. Accessed 3 December 2021.

Wellock, M.L., Reidy, B., LaPerle, C.M., Bolger, T. and Kiely, G. 2011a. Soil organic carbon stocks of afforested peatlands in Ireland. Forestry 84: 441-451.

Wellock, M.L., LaPerle, C.M. and Kiely, G. 2011b. What is the impact of afforestation on the carbon stocks of Irish mineral soils? Forest Ecology and Management 262: 1589-1596. 